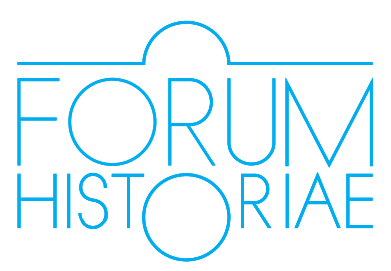

\title{
Personálna kontinuita politickej elity v Košiciach po Viedenskej arbitráži*
}

\author{
Veronika Szeghy-Gayer
}

\begin{abstract}
SZEGHY-GAYER, Veronika: Personnel Continuity of the Political Elite in Košice Following the Vienna Arbitration.

The Vienna Arbitration and coup d'état in 1938 resulted in changes in the make-up of the local political elite in towns ceded to Hungary. This study aims to answer the following questions that have scarcely been discussed so far:

- What role was played by the local Hungarian elite who were active in the minority policies during the existence of Czechoslovakia after the political changes of 1938?

- Who was granted a membership in the Municipal Committee of Košice and on what grounds?

- What was the diplomatic history of the new political elite of the municipality?

The author convincingly points to a significant personnel continuity between the political elite of Košice before and after 1938. Municipal management included public figures from Košice who had participated in local policy making for decades, even after the Vienna Arbitration. She thus revises a myth present in contemporary public discussion and historiography of a strong position of so called „anyás“ people in the arbitration territory. These were the clerks and civil servants who had arrived in Košice from Hungary in order to work in the state administration.

After the first Vienna Arbitration, the Municipal Committee of Košice, was comprised of the people who had socialized at the time of dualism. The majority of them had begun their political careers in the opposition during the time of the Czechoslovak Republic. A considerable part of the educated members had had at least ten years of experience in local politics and were also known to the Hungarian government due to their positions or memberships in Hungarian political parties.

From 1938 to 1945, the Municipal Committee was re-arranged to include exclusively Hungarians which did not reflect the diversity of political life during the inter-war period. Outside of the committee, there remained local representatives of left-wing movements with a quite large electoral support and Slovak positions were taken by politicians loyal to the Hungarian state.
\end{abstract}

Keywords: Košice, political elites, Vienna Arbitration, Municipal Committee

$\mathrm{V}$

predkladanej štúdii skúmam personálne zloženie politickej elity v Košiciach po Viedenskej arbitráži. Pod pojmom politická elita rozumiem členov municipálneho výboru, ${ }^{1}$ ktorí boli vymenovaní vtedajším ministrom vnútra Mad’arského královstva podla politickej spol’ahlivosti. Hladám odpoved' predovšetkým na otázku, aké zmeny nastali v rámci politickej elity mesta v dôsledku štátneho prevratu v roku 1938? Kto a na základe čoho získal členstvo v municipálnom výbore mesta Košíc a akou politickou minulost’ou disponoval? Akú úlohu zohrala miestna mad’arská elita, aktívna v rokoch 1918 - 1938 v menšinovej politike, po politickej premene v roku 1938? Do akej miery môžeme hovorit’ o novej reštrukturalizácii košickej elity v rámci vedenia mesta a do akej miery o vyplnení pozícií v mestskom zastupitel’stve osobami z Madarska?

\footnotetext{
* Túto prácu podporila Agentúra na podporu výskumu a vývoja na základe zmluvy č. APVV-14-0644 Kontinuity a diskontinuity politických a spoločenských elít na Slovensku v 19. a 20. storočí.

$1 \mathrm{~V}$ rokoch 1870 - 1918 Košice boli municipálne mesto, teda mesto s municipálnym právom (törvényhatósági jogú város). Na čele mesta stál hlavný župan, ktorý bol predstavitelom vládnej výkonnej moci, zástupcom vlády. Samosprávu tvoril municipálny výbor pozostávajúci z 50 \% virilistova 50 \% iných volených zástupcov obyvatel'stva. Po Viedenskej arbitráži, ked' mesto pričlenili k Mad’arsku, Košice boli znovu povýšené na municipálne mesto. Po nemeckej vojenskej okupácii Mad’arska členovia municipálneho výboru zostali na svojich miestach až do príchodu sovietskej armády do Košíc 19. januára 1945.
} 
Skúmanie spoločenských dejín Košíc po Viedenskej arbitráži je málo spracovanou témou, ako na to nedávno poukázali viacerí historici. ${ }^{2}$ Okrem propagandistických publikácií z obdobia druhej svetovej vojny a doteraz publikovanej memoárovej literatúry sa košickým udalostiam uvedených rokov venoval okrajovo len Michal Potemra vo svojich bibliografiách a v práci skúmajúcej každodenný život Slovákov. ${ }^{3}$ Slovenská marxistická historiografia vyprodukovala k tejto téme tiež niekol'ko zväzkov kníh, prevažne k tematike košických šípových krížov, ale tieto výskumy, prihliadnuc k dobovej ideológii, kládli prvoradý zretel’ na „zločiny mad’arského fašizmu“. Zo skúmaného obdobia je do istej miery spracovaná iba problematika holokaustu v Košiciach. ${ }^{5}$ A to aj napriek tomu, že Viedenská arbitráž a otázka revízie slovensko-mad’arských hraníc patria k frekventovaným témam mad’arskej a slovenskej historickej vedy. Deficity historiografie k tejto časti dejín Košíc sú determinované viacerými príčinami. Na jednej strane v slovenských prácach je to obdobie často vnímané ako kratšie „interregnum”, ktoré ako keby nebolo súčastou minulosti mesta. ${ }^{6}$ Problém je najmä v tom, že monografie a učebnice o dejinách Slovenska v prevažnej väčšine vychádzajú z národno-teritoriálneho princípu, teda sa venujú iba dejinám Slovákov a po roku 1918 dejinám slovenského štátu alebo územia, ${ }^{7}$ v dôsledku čoho minulost’ tzv. arbitrážneho územia a v rámci toho dejiny Košíc ostávajú ignorovanou problematikou.

Na druhej strane je potrebné brat’ do úvahy, že diskriminačné opatrenia proti mad'arskej menšine na Slovensku po roku 1945 (deportácie, reslovakizácia, presídlenie Mad’arov do Čiech, slovensko-mad’arská výmena obyvatel'stva) boli prijaté čiastočne pod vplyvom udalostí a vývoja po prvej Viedenskej arbitráži. ${ }^{8} \mathrm{~V}$ dôsledku toho sa Košice v druhej polovici 20. storočia stali slovenským mestom, kde je príbeh „mad’arských Košíc“ z časti súčast’ou nevyrozprávanej minulosti. ${ }^{9}$

2 VERES, Tímea. Košice v období rokov 1938 - 1945 - stav výskumu dejín mesta. In ŠUTAJ, Štefan (ed.). Košice a dejiny - Dejiny Košíc. Košice : UPJŠ FF, 2011, s. 148-152; SIMON, Attila. Magyar idők a Felvidéken 1938 - 1945. Az első bécsi döntés és következményei. Budapest : Jaffa Kiadó, 2014; SÁPOSOVÁ, Zlatica - ĎURKOVSKÁ, Mária. Možnosti výskumu osobnosti biskupa Madarásza s ohladom na jeho pôsobenie v Košiciach. In ŠUTAJ, Štefan (ed.). L’udia a dejiny - Historická biografia a jej miesto v historiografii. Košice : UPJŠ FF, 2016, s. 106-119, tu s. 107.

3 POTEMRA, Michal (ed.). Politický a hospodársky život v Košiciach v rokoch 1938 - 1945, Tematická bibliografia. I. Košice : Štátna vedecká knižnica v Košiciach, 1986; POTEMRA, Michal (ed.). Politický a hospodársky život v Košiciach v rokoch 1938 - 1945, Tematická bibliografia. II. Košice : Štátna vedecká knižnica v Košiciach, 1986; POTEMRA, Michal (ed.). Kultúrny život v Košiciach v rokoch 1938 - 1945: tematická bibliografia 1. Košice : Štátna vedecká knižnica v Košiciach, 1985; POTEMRA, Michal (ed.). Kultúrny život v Košiciach v rokoch 1938 - 1945 : tematická bibliografia 2. Košice : Štátna vedecká knižnica v Košiciach, 1985; POTEMRA, Michal (ed.). Kultúrny život v Košiciach v rokoch 1938 - 1945: tematická bibliografia 3. Košice : Štátna vedecká knižnica v Košiciach, 1985, s. 367-802; POTEMRA, Michal (ed.). Kultúrny život Slovákov na južnom Slovensku v rokoch 1938 - 1945. Bibliografia článkov z novín a časopisov na južnom Slovensku v rokoch 1938 - 1945. Košice : Štátna vedecká knižnica, 1993.

4 OLEXA, Ladislav - VIPLER, Vladimír. V tieni šípových krížov. Košice : Krajský dom osvety, 1959; VIETOR, Martin. Dejiny okupácie južného Slovenska. Bratislava : Vydavatel'stvo SAV, 1968.

5 ŠALAMON, Pavol - JUROVÁ, Anna (eds.). Košice a deportácie Židov v roku 1944. Košice : Spoločenskovedný ústav SAV, Oddelenie židovskej kultúry Slovenského národného múzea, 1994; GELLÉRT, Ádám. Csatári László és az 1944-es kassai deportálások. In Betekintő, 2014, roč. 8, č. 3, s. 1-29.

6 Pozri napríklad FERKO, Tibor. Divadelné letopisy mesta Cassa, Caschau, Kassa, Košice v súvislostiach dejín 1557 - 1945. Košice : Equilibria, 2013, s. 767-793.

7 Najnovšie pozri: PEKÁR, Martin. Dejiny Slovenska 1918 - 1945. Vysokoškolská učebnica. Košice : Univerzita Pavla Jozefa Šafárika v Košiciach Filozofická fakulta, 2015, s. 9.

8 Ako na to poukazuje aj neznámy autor predslovu monografie Loránta Tilkovszkého: „[...] dôsledky okupačného režimu našli svoj odraz aj vo formách riešenia mad’arskej otázky po oslobodení." In TILKOVSZKY, Loránt. Južné Slovensko v rokoch 1938 - 1945. Bratislava : Vydavatel'stvo Slovenskej akadémie vied, 1971, s. 5.

9 SIMON 2014, s. 10-11. 
Príklad multietnických Košíc je ale zaujímavý z viacerých hl’adísk. Košice boli na konci 19. a v prvej polovici 20. storočia symbolom (česko)slovensko-mad’arského súperenia o dnešné územie Slovenska, ked’že dobové sčítania l’udu potvrdzovali raz mad’arskú, inokedy slovenskú, resp. československú väčšinu, ${ }^{10}$ preto sa vo verejnej pamäti oboch národov vytvoril obraz etnicky homogénnych Košíc. ${ }^{11}$ Odhliadnuc od sociologickej analýzy košického židovstva od Évy Kovács ${ }^{12}$ či prípadovej štúdie Rastislava Kisel’a o činnosti Slovenskej ludovej strany v Košiciach, ${ }^{13}$ len vel’mi málo publikácií skúma miestnu elitu, alebo čo i len jej určitú skupinu, najmä ked' ide o obdobie rokov 1867 až 1945. ${ }^{14}$ Ďalej archontologická práca, resp. prozopografická štúdia o Košiciach bola vydaná len pre obdobie raného novoveku. ${ }^{15}$

V nižšie uvedenej analýze som vychádzala z personálneho zloženia mestského zastupitel'stva z januára 1939 (spolu 71 osôb). ${ }^{16}$ Okrem toho sa výskum zameral aj na tie osoby, ktoré v novembri 1942 (desat' osôb) ${ }^{17}$ a v roku 1943 (štyri osoby) ${ }^{18}$ obsadili uvol'nené miesta v municipálnom výbore. Neobsahuje však mená nových členov vymenovaných neskôr a ani náhradných členov. K tomu je ale potrebné dodat', že László Tost ${ }^{19}$ na poste hlavného predstavitel'a mesta zotrval menej ako rok a na jeho miesto bol v júni 1939 vymenovaný Sándor Pohl (jedna osoba), ${ }^{20}$ bývalý starosta z Újpestu, ktorý si svoju pozíciu udržal až do prevzatia moci Ferencom

10 SZEGHY-GAYER, Veronika. A szlovák-magyar-zsidó-cseh Kassa a 20. század első felében. In Korall, 2017, roč. 18, č. 3, s. 99-121.

110 rozdiele v ponímaní Košíc v pamäti dvoch národných spoločenstiev pozri: FICERI, Ondrej. Košice v slovenskej historiografii. Košice : Dejepisný spolok v Košiciach, 2016, s. 22.

12 KOVÁCS, Éva. Felemás asszimiláció. A kassai zsidóság a két világháború között (1918 - 1938). Somorja Dunaszerdahely : Fórum Kisebbségkutató Intézet - Lilium Aurum Könyvkiadó, 2004.

13 KISEL', Rastislav. Pohl'ad na činnost' Slovenskej l'udovej strany v Košiciach a okolí v kontexte komunálnych volieb v roku 1923. In Historica Carpatica, 2012, roč. 41-42, s. 63-114.

14 HENSCHEL, Frank. „Das Fluidum der Stadt...“ Urbane Lebenswelten in Kassa/Košice/Kaschau zwischen Sprachenvielfalt und Magyarisierung 1867 - 1918. Göttingen : Vandenhoeck \& Ruprecht, 2017. Práca sa venuje mestským elitám, meštanostom, komunálnej politike a elitným spolkom v Košiciach v období dualizmu. 0 rokoch 1938 - 1945 pozri: POTEMRA, Michal - KIRST, Jozef (eds.). Mestská správa v Košiciach v rokoch 1848 - 1945: tematická bibliografia. I. Košice : Štátna vedecká knižnica, 1984, s. 258-275; O období po roku 1944 pozri: ŠUTAJ, Štefan. Košice na konci druhej svetovej vojny - politické a spoločenské centrum Československa. In HAJDUOVÁ, Mária - BARTOŠ, Martin (eds.). Košice v súradniciach európskych dejín. Košice : Mesto Košice, Archív mesta Košice, 2014, s. 358-395.

15 NÉMETH, István H. Kassa város archontológiája. Bírák, belső és külső tanács. 1500 - 1700. Budapest: Szentpétery Imre Történettudományi Alapítvány, 2006; NÉMETH, István H. A hatalom dinamikája. A kassai városvezető elit általános jellemzői (16 - 17. század). In NÉMETH, István H. - SZÍVÓS, Erika - TÓTH, Árpád (eds.). A város és társadalma. Bácskai Vera tiszteletére. Budapest : Hajnal István Kör Társadalomtörténeti Egyesület, 2011, s. 311322.

16 Archív mesta Košice (dálej AMK), fond (d’alej f.) Košice - Mesto s municipiálnym zriadením 1939 - 1945, inv. č. 4.Kassa sz.kir. város törvényhatósági bizottságának 1939. évi május hó 4. napján tartott rendes gyűlésében tárgyalt ügyekről.

17 AMK, f. Košice - Mesto s municipiálnym zriadením 1939 - 1945, inv. č. 29.Kassa sz. kir. város törvényhatósági bizottságának 1942. évi november hó 18-án tartott rendkívüli ülésében tárgyalt ügyekről.

18 POTEMRA - KIRST 1984, s. 263.

19 Priezvisko nájdeme v dobovej tlači aj vo forme Toszt. Avšak v archívnych dokumentoch, ktoré som použila sa László Tost podpisoval ako Tost.

20 AMK, f. Košice - Mesto s municipiálnym zriadením 1939 - 1945, inv. č. 7. Kassa sz. kir. város törvényhatósági bizottságának - Dr. Pohl Sándor polgármester székfoglalója alkalmából - 1939. évi június 17. napján tartott ünnepi üléséról készült jegyzőkönyv. 
Szálasim, košickým rodákom, vodcom Strany šípových krížov. Napriek tomu, že analyzovaná vzorka nebude úplná, ${ }^{21}$ usúdila som, že týchto 86 členov zastupitel'stva poskytne dobrý pohlad na to, ktoré skupiny lokálnych politických elít sa po roku 1938 integrovali do vznikajúceho mad’arského štátneho zriadenia. Pri identifikácii skúmaných osobností som vychádzala zväčša z vlastných archívnych výskumov, v menšej miere z dobovej tlače, z mad’arských adresárov úradníkov (tiszti címtárak) alebo biografických lexikónov vzt’ahujúcich sa na Košice. ${ }^{22}$

Vo svojom príspevku by som chcela poukázat’ na skutočnost', že medzi politickou elitou Košíc pred rokom 1938 a po ňom existovala značná personálna kontinuita a že politické vedenie mesta pozostávalo aj po Viedenskej arbitráži z košických osobností pôsobiacich v miestnej politike už niekol'ko desat'ročí. Ide o dôležité zistenie z toho dôvodu, že v dobovej verejnej diskusii, ako aj v historických analýzach je prítomnost' tzv. skupiny „anyásov“ na arbitrážnom území vel'mi silná. Dobovým pejoratívnym pomenovaním „anyás“ označovali najmä tých úradníkov a štátnych zamestnancov, ktorí prišli do Košíc z materskej krajiny (anyaország), teda z Mad’arska po prvej Viedenskej arbitráži s ciel’om pracovat' v mad’arskej štátnej sfére. ${ }^{23}$

Pred začatím komárňanských rokovaní bola aj v Košiciach 7. októbra 1938 vytvorená Mad’arská národná rada. Tá po vyhlásení výsledkov Viedenskej arbitráže vymenovala za meštanostu Lászlóa Tosta, ktorý bol už od roku 1932 členom mestského zastupitel'stva a od marca 1933 zastával ako krest’ansko-socialistický politik funkciu námestníka starostu. Bol to práve Tost, kto 5. novembra 1938 prebral od československého vládneho komisára Jozefa Bučeka ${ }^{24}$ verejnú správu mesta. Pár dní neskôr, 11. novembra predpoludním, sa uskutočnil slávnostný vstup mad’arských jednotiek a regenta Miklósa Horthyho do Košíc. Hned' nato bola zavedená vojenská správa, ktorá zostala v platnosti až do 22. decembra 1938. Ustanovujúce slávnostné zasadanie municipálneho výboru sa uskutočnilo 28. januára 1939. Všetci členovia výboru sa ráno o ôsmej hodine zúčastnili v Dóme sv. Alžbety slávnostného Veni Sancte a po umiestnení vencov pred pamätnú tabul'u Františka II. Rákócziho sa v prítomnosti mad’arskej vlády a zástupcov župy premiestnili do historickej radnice mesta. ${ }^{25}$

Na území pričlenenom k Mad’arsku sa mohli stat' mad’arským štátnymi úradníkmi alebo verejnými zamestnancami len tí, ktorým počas tzv. overovacej previerky dokázali nespochyb-

21 T. j. analýza neobsahuje náhradných členov alebo členov, ktorí boli vymenovaní po roku 1943. Podla mojich výpočtov ide o približne 15 až 20 chýbajúcich osôb, ktoré nie sú uvedené ani v monografii Michala Potemru a Jozefa Kirsta POTEMRA - KIRST 1984, s. 263.

22 MIHÓKOVÁ, Mária. Slovník košických osobností 1848 - 1918. Košice : Štátna vedecká knižnica v Košiciach, 1995; KOLIVOŠKO Štefan et al. Slovník židovských osobností Košíc a okolia. Košice : Verejná knižnica Jána Bocatia, 2001; BLAŠKOVÁ, Eleonóra - GAŠPAR, Ján - MIHÓKOVÁ, Mária. Lexikón Košičanov : 1848 - 1938. 1. diel, A - I. Košice : Equilibria, s.r.o., 2014; MADARÁSZ, Elemér (ed.). Magyar politikai és közigazgatási compass: 1919 - 1939. Budapest : Magyar Politikai és Közigazgatási Compass (1919 - 1939) Kiadóvállalat, 1940.

23 Štefan Šutaj ešte k tomu dodáva, že skupina tzv. anyásov „[...] dostala majetok po vysídlených Čechoch a Slovákoch, prišli plnit' nariadenia Budapešti a uskutočňovali násilné pomad'arčovanie."ŠUTAJ 2011, s. 390.

240 ňom pozri: BYSTRICKÝ, Valerián - SEGEŠ, Dušan. Posledné dni slovenských Košíc. In Vojenská história, 2007, roč. 11, č. 4, s. 118.

25 Ünnepi közgyúlésen tért vissza Kassa városa a magyar élettérbe. In Felvidéki Magyar Hírlap, 29. januára 1939, s. 3-4. 
nitel'nú vernost' a lojálnost' k mad’arskému národu, ako aj ich politickú spol'ahlivost'. Počas previerok sa kládol prvoradý dôraz na národnú príslušnost’ a pri osobách nemad’arskej národnosti na lojalitu dotyčného k mad’arskému národu. ${ }^{26} \mathrm{~V}$ prípade členov košického municipálneho výboru sa miera „mad’arskej národnej vernosti“ posudzovala na základe ich aktivít počas existencie Československa. Rozhodujúcim bolo, či preverovaná osoba bola členom niektorej opozičnej mad’arskej politickej strany v Československu, spolupracujúcej s mad'arskými vládnymi kruhmi. V roku 1940 vydaný Mad'arský administratívny kompas (Magyar közigazgatási compass), ktorý obsahoval stručné životopisy najdôležitejších osobností vtedajšieho mad’arského politického a úradníckeho života, bol v tomto ohl'ade klúčovým dokumentom. O osobách uvedených v tomto lexikóne možno predpokladat', že ich lojalita k mad’arskému národu spred roku 1938 sa v dostatočnej miere preukázala. ${ }^{27}$ Pri členstve v mad’arských politických stranách sa zvýšený dôraz kládol na aktívnu účast’ v mad’arských menšinových spolkoch. Skúmalo sa, či konkrétna osoba nechala zapísat' svoje deti do mad’arských škôl, alebo či utrpela počas trvania Československa akúkol'vek, či už skutočnú alebo domnelú ujmu. Uplatnením týchto kritérií sa už vopred avizovalo, že politická paleta košického mestského zastupitel'stva sa oproti stavu spred roku 1938 zúži. K tomu všetkému je, samozrejme, potrebné dodat', že kým vol'by v prvej Československej republike boli všeobecné a tajné, v Mad’arsku boli sčasti verejné a sčasti tajné. Mad’arský volebný zákon z roku 1938 zaviedol tajné hlasovanie, vzdelanostný a majetkový cenzus sa stal prísnejší a ženy mohli volit' iba od 30 rokov. Ďalšou charakteristikou mad'arského volebného systému bola neustála zmena volebného zákona v záujme vytlačenia extrémistických strán. Počet l'udí s volebným právom od roku 1922 neustále klesal. Na dôvažok sa na územiach pripojených k Mad’arsku, a teda i v Košiciach, májové parlamentné vol'by roku 1939 neuskutočnili. ${ }^{28}$ To vyvolalo vel'ké sklamanie u obyvatelov Košíc, ktorí si za uplynulých 20 rokov zvykli na všeobecné a tajné hlasovacie právo.

Pri porovnaní politických kariér mnou skúmaných 86 osobností sa črtajú štyri väčšie skupiny: členovia bývalých menšinových strán a ich predpokladaní sympatizanti z radov inteligencie, bývalí československí štátni a mestskí zamestnanci, „anyási” a nakoniec slovenskí členovia. ${ }^{29}$ Okrem týchto sú d’alší jedenásti členovia výboru, ku ktorým sa mi nepodarilo nájst’ informácie či už k ich politickej straníckej príslušnosti, alebo iné kariérne záznamy.

Municipálny výbor Košíc v rokoch 1939 - 1945 z viacerých hladísk nereprezentoval obyvatel'stvo mesta, ktorého počet $\mathrm{v}$ dôsledku štátneho prevratu podla sčítania obyvatel'stva

26 CSILLÉR, Edit. A nemzethűség jelentése a felvidéki és kárpátaljai igazolási eljárások során. In Magyar Kisebbség, 2014, roč. 19, č. 1, s. 8.

27 MADARÁSZ 1940.

28 A választás és a Felvidék. In Felvidéki Magyar Hírlap, 4. mája 1939, s. 1.

29 Podla Jozefa Kirsta a Michala Potemru, sedem členov výboru boli „Slováci” a zároveň členovia Slovenskej krestanskej ludovej strany. Autori však uvádzajú len dve konkrétne mená: József Téglássi a Jozef Fischof. Okrem Téglássiho a Fischofa som v analýze zaradila ku Slovákom ešte Jánosa Onderuva a Andrása Pulika. Slovenský kaplán a jeden z organizátorov slovenského kultúrneho života v Košiciach v týchto rokoch, Anton Harčar, ich totiž spomína ako členov Slovenského katolíckeho kruhu. HARČAR, Anton. Žil som v Košiciach. Bratislava : Lúč, 2003. s. 114,124 . 
z decembra 1938 klesol z takmer 80-tisíc na 58-tisíc. ${ }^{30}$ Politické zastúpenie Slovákov pokleslo na minimum. V Košiciach sa podl'a mad'arského sčítania ludu v roku 1941 k tejto národnosti hlásilo vyše 4000 osôb. ${ }^{31}$ Jeden zo siedmich členov výboru, ktorí podla Jozefa Kirsta a Michala Potemru mohli byt' považovaní za Slovákov, bol Jozef Fischof, predstavitel' Slovenskej krest'anskej ludovej strany, ktorá sa začala formovat’ v januári 1939. ${ }^{32}$ Ku koncu roka zostal v Košiciach údajne už len jeden slovenský poslanec (József Téglássi), ktorý ale na zasadaniach nevystúpil ani raz. ${ }^{33}$

Podobnou radikálnou zmenou bolo aj to, že oproti medzivojnovému obdobiu sa zo zastupitel'stva municipálneho výboru úplne vytratili sociálnodemokratickí a komunistickí politici. Teda okrem toho, že municipálny výbor sa z národnostného hladiska pretvoril na výhradne mad’arský, neodzrkadloval ani jednotlivé aktívne politické zoskupenia Košíc z ideologickej stránky. Kým počas československej éry mali robotnícke strany medzi košickými voličmi v priemere tretinovú podporu, ba čo viac, v komunálnych vol'bách v roku 1932 odovzdali Československej komunistickej strane najviac hlasov, ${ }^{34}$ za členov nového municipálneho výboru nevymenovali ani jedného poslanca z radov košických komunistov či sociálnych demokratov. Tento fakt možno pripísat' jednak mad’arskému vnútropolitickému systému, ako i silnému pravicovému posunu Imrédyho vlády. Na túto skutočnost’ upozornil v roku 1939 počas januárového zasadnutia Sociálnodemokratickej strany košický mad’arský sociálny demokrat Géza Borovszky: „Nás v novembri 1938 oslobodili, ale ked’ bude na území Felvidéku v platnosti volebné právo z anyaországu, tak ja, ktorý som mohol byt' počas Československa zástupcom robotníctva v parlamente, možno prídem o právo volit' [...]. Z 56 vymenovaných je 54 pánov, jeden je cigán a jeden pseudorobotník. ${ }^{\prime 35}$ Cigán, ktorého Borovszky spomína, bol primáš Lajos Bikár. Toho v júni 1920 údajne „bezdôvodne” prepustili z Telegrafného stavebného úradu v Košiciach, kde pracoval ako robotník. ${ }^{36}$ V roku 1932 bol ako „cigánsky priemyselník” členom Mad’arskej národnej strany, neskôr vstúpil do radov Zjednotenej mad’arskej strany. ${ }^{37}$ Pod označením „pseudorobotník”

30 V historiografii zatial' nie je k dispozícii presný údaj o počte českých a slovenských utečencoch z Košíc, ani o nových mad’arských úradníkoch, ktorí prišli do Košíc po roku 1938. Podl’a Martina Pekára ide o zhruba 40tisíc evakuovaných osôb. PEKÁR, Martin. Evakuácia významných úradov a inštitúcií z Košíc do Prešova v roku 1938. In REGINÁČOVÁ, Nikola - BOJKOVÁ, Alžbeta (eds.). Historické medzníky vo vývoji Košíc. Košice : Univerzita Pavla Jozefa Šafárika v Košiciach Filozofická fakulta, 2013, s. 77; Podl’a výpočtov starostu Lászlóa Tosta približne 25000 l’udí opustilo Košice po štátnom prevrate v roku 1938. Pozri: Nemzeti zarándokhellyé kell kifejleszteni Rákóczi városát. Tost László polgármester előadása a budapesti Baross Szövetségben. In Felvidéki Magyar Hírlap, 14. januára 1939, s. 5.

31 1941. évi népszámlálás demográfiai adatok községenként /Országhatáron kívüli terület/ Kézirat. Budapest : Központi Statisztikai Hivatal, 1990, s. 230-231.

32 POTEMRA - KIRST 1984, s. 265.

33 Tamže, s. 265.

34 SZEGHY-GAYER, Veronika. Felvidékből Szlovenszkó. Magyar értelmiségi útkeresések Eperjesen és Kassán a két világháború között. Pozsony : Kalligram Kiadó, 2016, s. 113.

35 Elszakadtságunk idején mi nem tagadtuk meg szocialista voltunkat, de magyarságunkat sem. In Népszava, 31. januára 1939, s. 11-12.

36 AMK, f. Policajný kapitanát mesta Košice (1830) 1861 - 1922, krabica (d’alej k.) 219, inv. č. 9692/920. Bikár Lajos panasza a Telegrafičný stavebný úrad v Košiciach ellen 324 Kč. iránt.

37 Blanár Béla, Hercz Ignác és Greguss Gyula a magyar nemzeti párt listájának élén. In Prágai Magyar Hírlap, 5. 
mal Borovszky nepochybne na mysli drevospracujúceho robotníka Fedora Györgya, ktorý bol v medzivojnovom období ústrednou postavou miestneho krestansko-socialistického hnutia a „zástupcom krest’anského robotníctva”. ${ }^{38}$

Rovnako zásadnou zmenou bolo, že počet izraelitov sa v municipálnom výbore zredukoval na dvoch. Židovskú stranu a ostatné strany zastupujúce hospodárske a priemyselné záujmy košického židovstva zrušili a v zastupitel'skom výbore nemohli viest’ politickú debatu. Spomedzi politikov so židovským vierovyznaním boli po Viedenskej arbitráži za členov výboru vymenovaní len niekdajší zakladatelia Mad’arskej národnej strany, Béla Halmi a Ármin Wirkmann. Ked' 15. marca 1940 Zjednotená mad’arská strana vyhlásila svoje zlúčenie s Mad’arskou stranou života (vtedajšou vládnou stranou), ani jeden z nich sa k novej strane nepridal. Ich členstvo v municipálnom výbore skončilo na základe zákonného článku 19 z roku $1940^{39}$ a oficiálne boli vyradení z činnosti výboru v júni $1942 .^{40}$

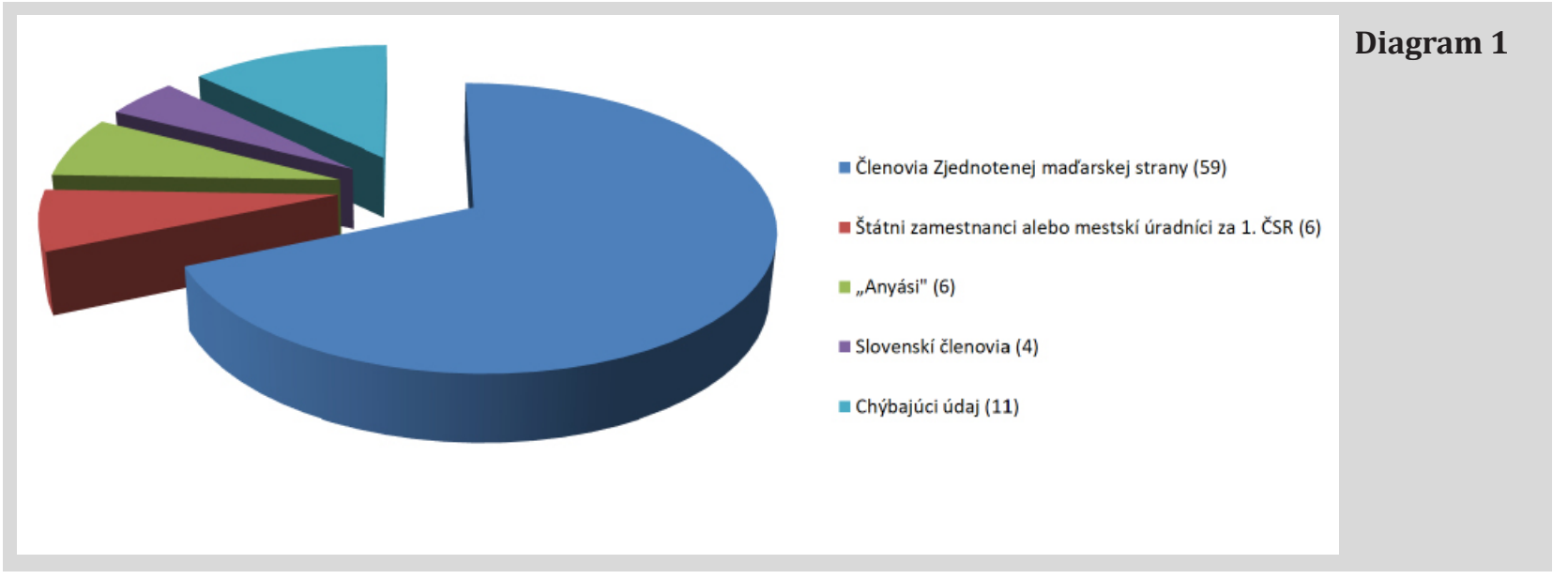

Vyššie uvedený diagram prezrádza, že väčšina členov výboru, spolu 55 osôb (64 \%), patrila ku košickým členom Zjednotenej mad’arskej strany vytvorenej v júni 1936 z Krajinskej krest’ansko-socialistickej strany a Mad’arskej národnej strany. K týmto som priradila d’alšie štyri osoby z kruhov inteligencie a podnikatelov, ktorí mali blízko k mad’arským stranám. Vychádzala som pritom z toho, v akých politických kruhoch sa dané osoby pohybovali, v akých spolkoch vykazovali členstvo a či sa zúčastňovali organizovaných akcií politických strán.

Z bývalých členov menšinovej elity je v prípade 47 osobností známa ich politická kariéra spred roku 1936: 36 boli členmi Krajinskej krest’ansko-socialistickej strany a jedenásti

apríla 1932, s. 3; A magyar egység nevében minden társadalmi osztály méltó képviseletet kapott az egyesült párt listáján. In Prágai Magyar Hírlap, 29. apríla 1937, s. 3.

38 Megalakult az egyesült párt keletszlovákiai és kárpátaljai munkásszakosztálya. In Prágai Magyar Hírlap, 23. februára 1938, s. 4.

39 1941. évi XIX. törvénycikk a törvényhatósági bizottsági és a községiképviselőtestületi tagsági jogról, továbbá a gyakorlati közigazgatási vizsgára vonatkozó átmeneti szabályokról. Dostupné na internete: https://1000ev.hu/ index.php?a=3\&param=8172 [16.4.2018]

40 AMK, f. Košice - Mesto s municipiálnym zriadením 1939 - 1945, inv. č. 26., Kivonat Kassa sz.kir.város törvényhatóásig bizottságának 1942.évi június hó 17-én tartott rendes ülésében készült jegyzőkönyvől, č. spisu 17681/66/1942.kgy.szám. 
členmi Mad'arskej národnej strany. Táto skupina politikov predstavovala kontinuitu s obdobím spred roku 1938, ked’že 13 z nich boli počas trvania Československej republiky zastúpení v mestskom zastupitel'stve (devät' krest’anských socialistov, štyria členovia Mad’arskej národnej strany). Najdlhšie, spolu vyše 29 rokov (v rokoch 1915 - 1918 a 1925 - 1945), sedel vo vedení mesta farár Barnabás Tost, zástupca miestneho krest’anského socializmu, ktorý už v roku 1915 bol ako biskupský tajomník členom municipálneho výboru. ${ }^{41}$ Po Viedenskej arbitráži sa stal poslancom hornej snemovne mad’arského parlamentu. ${ }^{42}$ Rovnako dlhú 29-ročnú politickú kariéru mali aj právnik Miklós Pajor a stavitel' Gyula Wirth (obaja v rokoch 1923 - 1945).

Ak sa posunieme d’alej do minulosti, tak spomedzi skúmaných osobností až ôsmi mali skúsenost' s členstvom municipálneho výboru pred rokom 1918 (Lajos Barcs, Béla Buchner, Lajos Czigler, Béla Halmi, Barnabás Tost, Károly Vukovich, Arisztid Aranyossy a Tivadar Münster). V medzivojnovom období sa štyria z nich stali mad’arskými straníkmi.

Tab. 1 Členovia municipálneho výboru Košíc v rokoch 1939 - 1944, ktorí predstavujú kontinuitu v mestskej politike.

\begin{tabular}{|c|c|c|c|c|}
\hline & Meno & Člen municipálneho výboru 1867 - 1918 & Člen mestského zastupitel'stva 1918 - 1938 & Strana \\
\hline 1. & Aranyossy Arisztid & + & - & $?$ \\
\hline 2. & Barcs Lajos & + & - & $?$ \\
\hline 3. & Bauernébl Szilárd, ml. & jeho príbuzný & - & $?$ \\
\hline 4. & Buchner Béla & + & $1937-1938$ & KKS \\
\hline 5. & Czigler Lajos & + & - & - \\
\hline 6. & Bucher Béla & + & $1937-1938$ & KKS \\
\hline 7. & Gönczy Gábor & - & $1923-1927,1937-1938$ & MNS \\
\hline 8. & Halmi Béla & + & $1927-1937$ & MNS \\
\hline 9. & Münster Tivadar, ml. & + /aj jeho príbuzný/ & $1937-1938$ & MNS \\
\hline 10. & Oelschläger Ferenc & jeho príbuzný & - & KKS \\
\hline 11. & Pajor Miklós & - & $1920-1927,1932-1938$ & KKS \\
\hline 12. & Pausz Béla & - & $1932-1938$ & KKS \\
\hline 13. & Radványi Géza & - & $1937-1938$ & KKS \\
\hline 14. & Resatkó Endre & - & $1937-1938$ & KKS \\
\hline 15. & Szakmáry Károly & jeho príbuzný & - & KKS \\
\hline 16. & Sziklay Ferenc & jeho príbuzný & - & KKS \\
\hline 17. & Tost Barnabás & + & $1920-1938$ & KKS \\
\hline 18. & Tost László & jeho príbuzný & $1932-1938$ & KKS \\
\hline 19. & Ványai István & - & $1927-1938$ & KKS \\
\hline 20. & Vukovich Károly & + & - & - \\
\hline 21. & Wirth Gyula & jeho príbuzný & $1923-1938$ & KKS \\
\hline 22. & Wirkmann Ármin & - & $1927-1932$ & MNS \\
\hline
\end{tabular}

Vysvetlivky: Bol členom +

Nebol členom -

KKS - Krajinská krest'ansko-socialistická strana

MNS - Mad'arská národná strana

41 Kassa sz.kir.város törvényhatósági bizottságának tagjai az 1915. évben. In Város Közlöny, Kassa Szab. Kir. Város Hivatalos Lapja, 15. januára 1915, s. 1.

42 Kassa sz.kirváros törvényhatósági bizottságának tagjai az 1915. évben. In Város Közlöny, Kassa Szab. Kir. Város Hivatalos Lapja, 15. januára 1915, s. 1. O ňom ako aktérovi cirkevného života v Košiciach: ZUBKO, Peter. Košický farár Barnabás Tost (1918 - 1938). In ŠUTAJ, Štefan (ed.). L'udia a dejiny - Historická biografia a jej miesto $v$ historiografii. Košice : UPJŠ FF, 2016, s. 93-105. 
Popri Tivadarovi Münsterovi, ktorého otec zastával v rokoch 1872 až 1906 pozíciu košického meštanostu, tu nájdeme d’alších šest' osôb, ktorých rodinní príslušníci zastávali pred rokom 1918 vo vedení mesta nejakú politickú funkciu. Szilárd Baurnébl mladší bol z spomedzi 86 osôb jediný, ktorý mohol o sebe prehlásit’, že nie len on sám, ale aj jeho otec a starý otec nosili mestskú hodnost' v období, ked' boli Košice súčastou Uhorska i Mad’arska. Szilárd Bauernébl mladší sa zároveň stal členom Hornej snemovne mad’arského parlamentu po roku 1938. ${ }^{43}$

Do samostatnej kategórie radím d’alších šest' členov municipálneho výboru, ktorí predtým neboli členmi mad’arských strán, ba dokonca v ére Československa pracovali v mestskej administratíve alebo štátnej správe, a napriek tomu dokázali po roku 1938 preukázat’ svoju „národnú vernost'” k mad’arskému štátu. Patril medzi nich Károly Vukovich, ktorý pôsobil v službách mesta už od roku 1906. V otázke oddanosti bol Vukovich spol’ahlivý zrejme preto, že jeho brat István zastával v tej istej dobe členskú pozíciu v Mad’arskej národnej strane. ${ }^{44}$ Lajos Valkay bol mestským poslancom od roku 1913 a svoje miesto si ponechal aj po štátoprávnych zmenách v roku 1918, ba dokonca v roku 1937 ho vymenovali za administratívneho komisára mesta. Jeho meno sa napriek tomu dostalo do Mad’arského administratívneho kompasu, v ktorom nasledovne vysvetl'ujú jeho postoj k vtedajšiemu zloženiu prísahy Československu: „V zotrvaní na svojich pozíciách počas českej vlády, videl [Valkay] spôsob ako slúžit’ mad’arstvu. “45

Vilmos Koch sa stal členom municipálneho výboru na konci roka 1942. V roku 1937 odišiel do dôchodku, predtým učil na vyššom stupni mad’arského oddelenia vyššej priemyselnej školy. ${ }^{46}$ István Rédeky pracoval pre Košice od roku 1914. Po vzniku Československej republiky bol v roku 1923 vymenovaný za hlavného mestského prokurátora. Neskôr to Rédeky v mad’arských politických kruhoch odôvodňoval tak, že „[...] mad'arský človek nesmie dobrovol'ne prenechat' novej moci ani piad' zeme, ale že má v záujme ochrany Mad'arstva vytrvat' do konca, ja som svoje miesto neopustil, ale spolu s väčšinou mojich spolupracovníkov som si ho udržal tak, aby som ubránil mad’arské záujmy." "77 Svoju mad’arskú národnú vernost' obhajoval aj tým, že v júni 1937 bol zo zamestnania prepustený práve kvôli tomu, že 28. októbra 1936 nevyvesil na svoj dom československú štátnu vlajku a neurobil to ani po vyzvaní políciou. ${ }^{48}$ Po tomto incidente sa stal členom Zjednotenej mad’arskej strany, čo mu potom poslúžilo ako dostatočný dôkaz jeho politickej spol'ahlivosti. ${ }^{49}$

Poslednú skupinu tvorí šest’ osôb, ktoré sa do Košíc pristáahovali po Viedenskej arbitráži z predarbitrážneho územia Mad’arska. Okrem už vyššie spomenutého starostu Sándora Pohla

43 Az 1939. június hó 10-ére összehívott országgyűlés felsőháza tagjainak név-és lakjegyzéke. Budapest : Atheneum Irodalmi és Nyomdai Részvénytársulat, (1943), s. 22.

44 A szlovenszkói országos hivatal betiltottaa magyar nemzeti párt ifjúsági szervezkedését. In Prágai Magyar Hírlap, 21. júl 1933, s. 1.

45 MADARÁSZ 1940, s. 726.

46 Koch Vilmos tanár nyugalomba vonult. In Prágai Magyar Hírlap, 5. februára 1937, s. 5.

47 AMK, fond Mestský národný výbor v Košiciach 1945-48, inv. č. 95, k. 9, č. spisu 84/943, Dr. Štefan Rédeky. 48 AMK, fond Mestský národný výbor v Košiciach 1945-48, inv. č. 95, k. 9, č. spisu 84/943, Dr. Štefan Rédeky. 49 Lelkes nagygyűlésen alakult meg az egyesült párt rozsnyói járási szervezete. In Prágai Magyar Hírlap, 24. febrára 1937, s. 2. 
na druhom mieste spomenieme Gyulu Porubszkého, ktorý pôsobil v polovici 20. rokov na debrecínskom policajnom kapitánstve, ${ }^{50}$ neskôr sa dostal do Budapešti a odtial' ho vymenovali do Košíc za hlavného policajného kapitána. ${ }^{51}$ Košický policajný aparát bol zložený takmer výlučne z l’udí pochádzajúcich z územia Mad’arska.

Taktiež premonštrátsky kňaz Emil Buczkó slúžil u premonštrátov v meste Gödöllő a po roku 1938 bol vymenovaný za školského radcu v Košiciach. Do Košíc bol ministrom vnútra preložený aj István Röthler, predtým hlavný župný lekár v Békéšskej župe. ${ }^{52} 0$ posledných dvoch úradníkoch, ktorí boli preložení do Košíc z Mad’arska, som našla pomerne málo informácií. János Alberti pracoval v roku 1938 v Miškolci ako hlavný lesný radca a po preložení do Košíc sa stal lesným dozorcom. ${ }^{53}$ Endre Kollonay pôsobil v rokoch 1920 - 1938 v Kisvárde (spojené župy Szabolcs a Ung) ako mestský zverolekár. ${ }^{54}$ Obaja mali vzt’ah aj k územiu pripojenému v roku 1918 k Československu. Kým Alberti bol do rozpadu monarchie hlavným radcom v Gemeri, ${ }^{55}$ tak Kollonay slúžil v Bratislave, ale aj v Spišskom Podhradí. ${ }^{56}$

Priemerný vek 56 osôb (65,1%) spomedzi skúmaných 86 členov municipálneho výboru Košíc predstavoval 54 rokov. Medzi členmi nebola žena. Na porovnanie, v medzivojnovom období

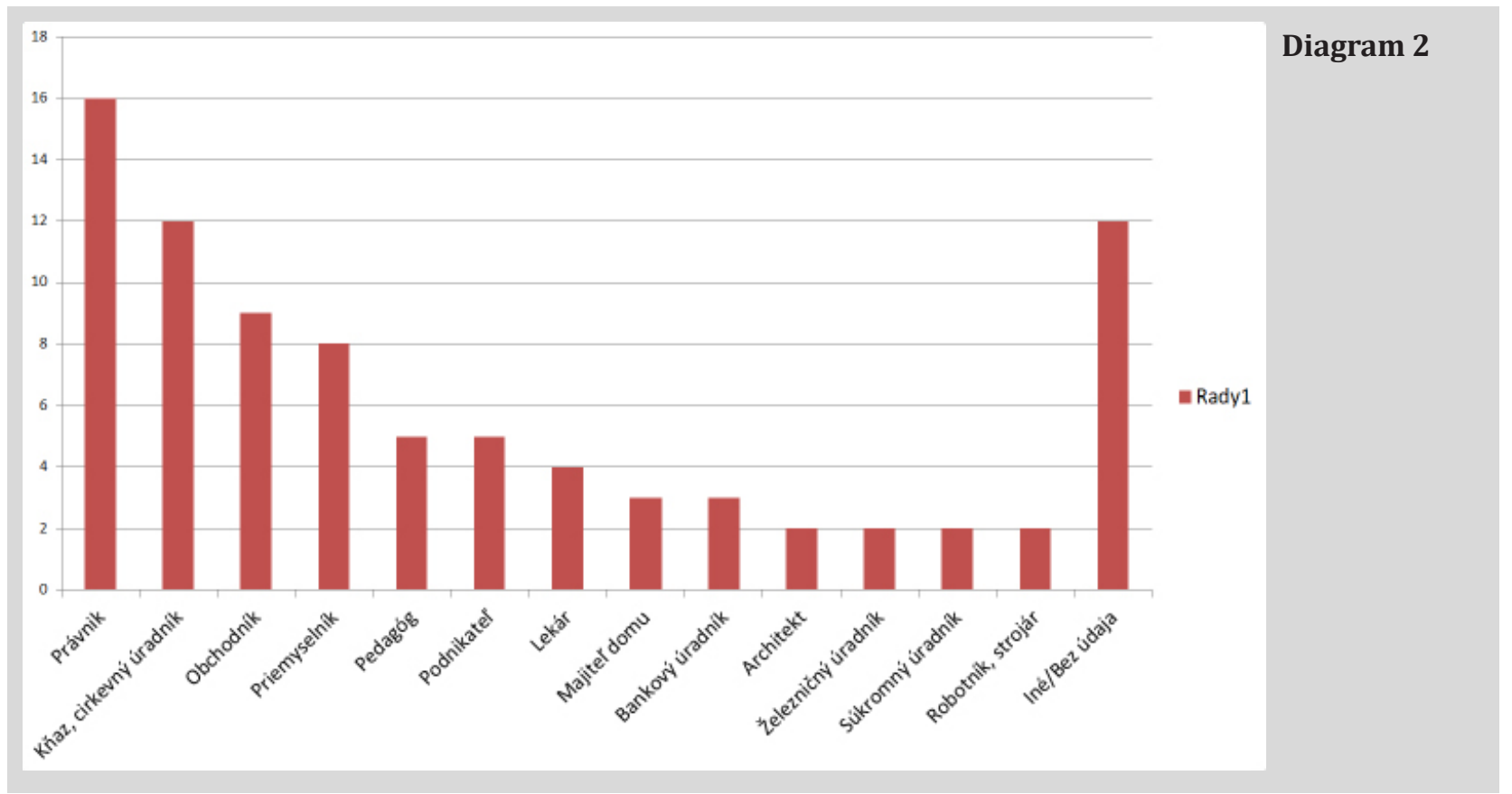

50 Porubszky József rendőrtanácsost nevezte ki a belügyminiszter a kassai kapitányság vezetőjévé. In Felvidéki Újság, 31. decembra 1938, s. 2.

51 Tamže, s. 2.

52 Röthler István vármegyei tisztifőorvost Kassára helyezik át. In Békésmegyei Közlöny, 22. decembra 1938, s. 3. 53 Magyarország tiszti czím- és névtára. XXXXVI. évfolyam. Budapest : 1938, s. 173.

54 Magyarország tiszti czím- és névtára. XXXVIII. évfolyam. Budapest : 1927, s. 192; Magyarország tiszti czím- és névtára. XXXXVI. Évfolyam. Budapest : 1938, s. 177.

55 Magyarország tiszti czím- és névtára. XXXVII. évfolyam. Budapest : 1918, s. 328.

56 Magyarország tiszti czím- és névtára. XXXII. évfolyam, Budapest: Pesti Könyvnyomda-részvénytársaság, 1913, s. 365; Magyarország tiszti czím- és névtára. XXXVI. évfolyam, Budapest : Pesti Könyvnyomda-részvénytársaság, 1917, s. 403. 
mali komunisti v mestskom zastupitel'stve tri, krest’ansko-sociálni dve a Československá národná socialistická strana jednu ženskú členku. Z nasledujúceho diagramu, v ktorom som kategorizovala jednotlivých členov podla pôvodného povolania, sa dá vyčítat' aj to, že väčšina z nich mala advokátsku prax, alebo to boli osoby z cirkevného prostredia, prípadne obchodníci a priemyselníci. Osoby, u ktorých som pôvodné zamestnanie nezistila, som zaradila do kategórie: bez údaja.

\section{Záver}

Na základe vyššie uvedených údajov, ktoré ešte bude potrebné v budúcnosti doplnit', možno konštatovat', že municipálny výbor Košíc po Viedenskej arbitráži pozostával z osôb, ktoré študovali v čase dualizmu a ktorých prevažná väčšina začínala svoju politickú kariéru v opozícii za trvania Československej republiky. Vel'ká čast' skúmaných poslancov disponovala aspoň desat'ročnou praxou v miestnom politickom živote a vd’aka pozíciám či členstvám v mad’arských politických stranách boli známi aj pre mad’arské vládne kruhy.

Personálne zloženie municipálneho výboru mesta v rokoch 1938 - 1945 však neodzrkadlovalo ani multietnický charakter Košíc, ani rôznorodost’ politického života z medzivojnového obdobia. Mimo výboru totiž zostali miestni reprezentanti lavicových hnutí s pomerne vysokou voličskou podporou. Svoju činnost' mohli prezentovat' nanajvýš v ilegalite. Poslanecké miesta vyčlenené pre Slovákov zaujali politici lojálni mad’arskému štátu. Ku všetkému je potrebné dodat', že po Viedenskej arbitráži opustili Košice desat'tisíce osôb. Išlo prevažne o tých českých a slovenských úradníkov, ktorí by boli v prípade zotrvania schopní vytvorit’ dostatočne silný opozičný protipól. Tým, že nútene či dobrovol'ne opustili mesto, výrazne ulahčili prácu mad’arským vládnym kruhom. Úplne opačný prípad sa stal po štátnom prevrate v rokoch 1918 - 1919, kedy sa muselo československé vedenie mesta vyrovnat’ s miestnou silnou mad’arskou opozíciou.

Vojenské obete druhej svetovej vojny, holokaust, vysídlenie, výmena obyvatel'stva a reslovakizácia Mad’arov mali za následok, že miestna elita skúmaná v tejto štúdii takmer vymizla zo života Košíc. Viacerých postavili pred súd, či už v Československu alebo Mad’arsku. Dňa 5. januára 1945 padol do pasce stúpencov nyilasov László Tost, ktorého popravili, pričom jeho manželku v júni 1947 presídlili do Mad’arska. ${ }^{57}$ Károly Poledniak, ${ }^{58}$ Gyula Wirth, ${ }^{59}$ Ferenc Grusetky ${ }^{60}$ ako aj Kálmán Kátra ${ }^{61}$ zahynuli v ruských vojenských zajateckých táboroch. Ármin Wirkmann sa stal obet’ou holokaustu. ${ }^{62}$ Barnabása Tosta vysídlili do mad’arskej obce Hejce. Osudy mnohých

57 AMK, fond Mestský národný výbor v Košiciach 1945-48, inv. č. 97, k. 459, Mária Tóstova, Vyšetr. odd. č. spisu. 53394/47, Hlásenie, Košice dňa 9. augusta 1947.

58 Dostupné na internete: https://kosicednes.sk/pribehy/dedko-sa-musi-v-hrobe-obracat/ [16.4. 2018]

59 Dostupné na internete: http://wirthnet.hu/WGY/Wgy1.htm [16.4. 2018].

60 BLAŠKOVÁ - GAŠPAR - MIHÓKOVÁ 2014, s. 358.

61 Štátny archív v Košiciach, fond Okresný l’udový súd v Košiciach, 1945 - 1947, č. kr. 45, inv. č. 110/47. Trestná vec: Dr. Koloman Kátra.

62 Dostupné na internete: http://yvng.yadvashem.org/nameDetails.html?language=en\&itemId=4338835\&ind=0; 
sú po roku 1945 dodnes neznáme. No nepochybne boli aj také rodiny, ktoré sa reslovakizovali a zostali v Košiciach. Ich dejinné príbehy nie sú osvetlené.

Skutočnú cezúru v dejinách Košíc a miestnej politickej elity predstavuje koniec druhej svetovej vojny, ked’že práve vtedy sa symbolicky a definitívne uzavrelo „mad’arské obdobie“ tohto mesta. Po roku 1948 sa dostala k moci elita, ktorá odmietla československú občiansku a mad’arskú minulost' a na základoch ideológie internacionalizmu pracovala na vybudovaní nových československých Košíc.

[16.4. 2018]; Béla Halmi zomrel v sanatóriu v Budapešti. In Magyarországi Zsidók Lapja, 20. júla 1944, s. 2.

Cituj:

SZEGHY-GAYER, Veronika. Personálna kontinuita politickej elity v Košiciach po Viedenskej arbitráži. In Forum Historiae, 2018, r. 12, č. 1, s. 129-140. ISSN 1337-6861.

Veronika Szeghy-Gayer, PhD. Oddelenie historických fondov Štátna vedecká knižnica v Košiciach gayerveronika@gmail.com 